\title{
Contents, Vol. 34, 1977
}

\section{Vol. 34,1977}

Index

No.1

Fónagy, I.: Le statut de la phonostylistique (Principle of Phonostylistics)

Malécot, A. and Chollet, G.: The Acoustic Status of the Mute-e in French ....

Haag, W. K.: Oral Air Pressure and Airflow in German Stop Consonants

Marchal, A.; Tiffou, E. et Warren, R.: A propos du «VOT»: le cas du bourouchaski

(On 'VOT': The case of Bourouchaski)

40

Gandour, J.: On the Interaction between Tone and Vowel Length: Evidence from

Thai Dialects

Libri $\quad 66$

No. 2

Pilch, H.: Intonation in Discourse Analysis. With Material from Finnish, English,

Alemannic German 81

Vance, T. J.: Tonal Distinctions in Cantonese

93

Kempgen, S.: Syntagmatische Phonemtypologie

(Syntagmatic Typology of Phonemes)

International Society of Phonetic Sciences. Officers, Members for 1976

No. 3

Pilch, H.: Baseldeutsche Phonologic Auf Grundlage der Intonation

(Intonational Phonology of Basel German)

165

Prabhakar Babu, B. A.: Emphasis in Telugu

Wode, H.: The L2 Acquisition of $/ \mathrm{r} / \quad 200$

McCasland, G. P.: English Stops after/s/ at Medial Word-Boundary

Libri 229

Varia 244

No. 4

The Larynx and Language

Proceedings of a Discussion Seminar at the

8th International Congress of Phonetic Sciences,

Leeds, August 17-23, $1975 \quad 245$

Index IV

No. 5

MacKay, I. R. A.: Tenseness in Vowels: an Ultrasonic Study

Kuenzel, H.J.: Photoelektrische Untersuchung zur Velumhöhe bei Vokalen: erste Anwendung des Velographen (A Photoelectric Investigation of Velar Height during Vowel Articulation: First

Applications of the Velograph)

Breen, J. G.: Andegerebenha Vowel Phonology

Libri 392

No. 6

Glave, R. D. und Lancé, D.: Segmentation und phonetische Klassifikation mit dem

DAWID-System

(Segmentation and Phonetic Classification by the DAWID System) 405

Christe, R.; Lhote, E.; Gassmann, M. et Grange, M.-F.: Quelques problèmes

poses par Гintroduction de la linguistique dans $\Gamma$ analyse des troubles d'articulation

et de parole

(Some Problems Posed by the Linguistic Introduction in the Analysis of Troubles

of Articulation and Speech)

423 
Ho, A. T.: Intonation Variation in a Mandarin Sentence for Three Expressions: Interrogative. Exclamatory and Declarative

446

Libri 458

Index autorum 474 